Vol. 3 No 2, Agustus 2021

ISSN 2657-0203

e-ISSN 2686-0244

\title{
PKM PENGENALAN ANDROID DAN PEMBUATAN VIDEO STREAMING DENGAN ANDROID STUDIO PADA SMK TELEKOMUNIKASI TELESANDI BEKASI
}

\author{
Intan Dwi Fatmaningtyas ${ }^{1}$, Jafar Shadiq ${ }^{2}$, Rita Wahyuni Arifin ${ }^{3}$, Ahmad Safei ${ }^{4}$, \\ Rayhan Wahyudin Ratu Lolly ${ }^{5}$ \\ Universitas Bina Insani \\ Rekayasa Perangkat Lunak ${ }^{1,2,4,5}$, Manajemen Informatika ${ }^{3}$, Fakultas Informatika, \\ Universitas Bina Insani \\ intandwi@binainsani.ac.id ${ }^{1}$, jafarshadiq@binainsani.ac.id ${ }^{2}$, \\ ritawahvuni@binainsani.ac.id ${ }^{3}$, svafei456@gmail.com ${ }^{4}$, \\ ravhan.wahvudin21@gmail.com ${ }^{5}$
}

\begin{abstract}
Abstrak
Pada era Covid-19 saat ini semakin banyak pengguna atau user yang menggunakan teknologi. Dari orang tua hingga anak kecil menggunakan teknologi sebagai alat media pembelajaran online dimasa pandemi Covid-19. Android saat ini menjadi pilihan bagi perusahaan teknologi yang menginginkan sistem operasi berbiaya rendah, bisa dikustomisasi, dan ringan untuk perangkat berteknologi tinggi tanpa harus mengembangkannya dari awal. Faktor di atas telah memberikan kontribusi terhadap perkembangan Android, menjadikannya sebagai sistem operasi telepon pintar yang paling banyak digunakan di dunia. Metode dalam PkM ini dengan sasaran utama adalah siswa-siswi jurusan Rekayasa Perangkat Lunak kelas XII pada SMK Telekomunikasi Telesandi Bekasi. PkM dilakukan dengan memberikan pelatihan dan demonstrasi kepada peserta dalam pembuatan video streaming dengan Android Studio dengan dukungan media online berupa zoom, YouTube dan Link Google Drive. Adapun hasil umpan balik yang diberikan oleh peserta yang disampaikan oleh narasumber dengan tingkat kepuasan secara keseluruhan 55.3\% memberi respon puas terhadap kegiatan pelatihan.
\end{abstract}

Kata kunci-android studio, pengabdian masyarakat, video streaming.

\footnotetext{
Abstract

In the Covid-19 era, more and more users are using technology. From parents to young children using technology as an online learning media tool during the Covid-19 pandemic. Android is currently the choice for technology companies who want a low-cost, customizable, lightweight operating system for high-tech devices without having to develop it from scratch. The above factors have contributed to the development of Android, making it the most widely used smartphone operating system in the world. The method in PkM with the main target is students majoring in Software Engineering class XII at SMK Telekomunikasi Telesandi Bekasi. PkM is carried out by providing training and demonstrations to participants in making video streaming with Android Studio with online media support in the form of zoom, YouTube and Google Drive links. The results of the feedback given by participants were delivered by sources with an overall satisfaction level of $55.3 \%$ giving a satisfied response to the training activities. 
Intan Dwi Fatmaningtyas, Jafar Shadiq, Rita Wahyuni Arifin, Ahmad Safei, Rayhan Wahyudin Ratu

Vol. 3 No 2, Agustus 2021

ISSN 2657-0203

e-ISSN 2686-0244

Keywords—android studio, community service, video streaming.

\section{PENDAHULUAN}

SMK Telekomunikasi Telesandi Bekasi merupakan sekolah yang didirikan dengan dilatarbelakangi oleh keinginan untuk meningkatkan kualitas pendidikan di bidang Teknologi di wilayah Bekasi, yang pada saat itu belum tersedia sekolah kejuruan bidang teknologi informasi dan telekomunikasi. SMK Telekomunikasi Telesandi Bekasi berdiri pada tahun 2008 dengan akreditasi "A". SMK Telekomunikasi Telesandi Bekasi berada dibawah naungan Yayasan Global Jaya Mandiri.

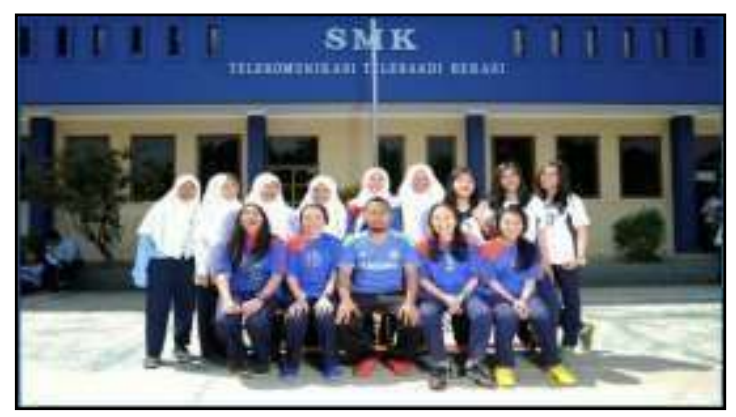

Gambar 1. Gedung SMK Telekomunikasi Telesandi Bekasi

Tidak lama ini dunia sedang diguncang dengan adanya virus corona atau yang sekarang disebut dengan Covid- 19 (Corona Virus Desease) (Wardani and Ayriza, 2020). Pada era Covid-19 saat ini semakin banyak pengguna atau user yang menggunakan teknologi. Dari orang tua hingga anak kecil menggunakan teknologi sebagai alat media pembelajaran online

dimasa pandemi Covid-19. Tidak seperti

dulu, masih jarang yang menggunakan teknologi dalam kehidupan manusia. Kini teknologi semakin berkembang dengan pesat, salah satunya adalah android yang berfungsi untuk membuat aplikasi berbasis android yang dijalankan pada telepon selular. Dengan adanya teknologi android, pengguna telepon selular dapat melakukan kreasi sendiri ataupun mengunduh aplikasi android untuk kemudian digunakan pada telepon selularnya (smartphone) (Pratama, 2017). UNESCO (United Nations Educational, Scientific and Cultural Organization) menyarankan kita menggunakan pembelajaran jarak jauh. Membuka platform pendidikan yang dapat digunakan sekolah agar menjangkau peserta didik dan membatasi gangguan pendidikan (Setiawan and Mufassaroh, 2020). Dengan adanya pembelajaran jarak jauh membutuhkan suatu alat yakni smartphone. Melalui smartphone kita dapat berbagai informasi dengan cepat dengan kejadian yang sedang terjadi saat ini. Keterbatasan informasi terkait dengan pembelajaran menjadi suatu permasalahan yang harus dicari solusinya. Sudah 
Intan Dwi Fatmaningtyas, Jafar Shadiq, Rita Wahyuni Arifin, Ahmad Safei, Rayhan Wahyudin Ratu

Vol. 3 No 2, Agustus 2021

ISSN 2657-0203

e-ISSN 2686-0244

selayaknya tersedia fasilitas dari media maupun sarana yang dapat memperoleh informasi

terkait pembelajaran

melalui video streaming pembelajaran.

Dalam pembuatan video streaming berbasis android perlu dikomunikasikan antar semua tim sehingga aplikasi berfungsi dengan baik. Untuk meminimalisir yang akan terjadi maka tim perlu merancang design dan mengumpulkan media terlebih dahulu. Pembuatan video streaming berbasis android menggunakan tools yang tersebar cukup banyak di internet baik itu yang gratis maupun berbayar. Salah satunya adalah aplikasi berbasis android adalah android studi. Android studio merupakan sebuah Integrated Development Environment (IDE) khusus untuk membangun aplikasi yang berjalan pada platform android (Al Fikri, 2016).

Penulis Ryzki Fajar dalam penelitiannya membuat rancang bangun aplikasi Video Streaming menggunakan real time streaming protocol (RTSP) berbasis android. Perancangan ini diharapkan dapat dilakukan dengan mudah. Kata kunci: Real Time Streaming Protocol (RTSP), video streaming, Android. Perkembangan teknologi video surveillance system atau kamera pengawas berkembang sangat pesat dan sudah menjadi alat yang sangat penting dan pokok, karena kebutuhan masyarakat sekarang ini yang menginginkan keamanan yang extra pada tempat yang tidak dalam area pengawasan pemilik tempat tersebut. Seiring dengan kebutuhan video

surveillance system yang semakin meningkat setiap kurun waktu tertentu maka diperlukan juga tingkat kualitas layanan, performansi dan kehandalan video streaming itu sendiri yang bertugas menjalankan video surveillance system Sistem video streaming yang digunakan saat pertama kali sampai dengan sekarang telah jauh berkembang (Ramadhan et al., 2020).

Penulis lain Ahmad Roihan, dkk pun melakukan penelitian yang menggunakan aplikasi Android Studio dalam implementasi metode realtime, live data dan parsing JSON berbasis mobile dengan android studio dan PHP native. Pembuatan aplikasi mobile yang berbasis android di jaman sekarang ini telah mencapai kemajuan yang sangat besar terutama aplikasi yang berhubungan dengan pendataan mahasiswa dalam sebuah seminar. Sistem aplikasi yang berhubungan dengan pendataan mahasiswa merupakan salah satu bagian yang sangat penting dalam pengelolaan data. Penggunaan sistem yang terkomputerisasi akan lebih banyak menghemat waktu, tidak banyak menyita tenaga, dan menghasilkan keakuratan penyajian data apalagi ditambah dengan sistem database sebagai media penyimpanan datanya (Roihan et al., 2019). Berdasarkan penjelasan diatas dan untuk mendukung tercapainya visi dan 
Intan Dwi Fatmaningtyas, Jafar Shadiq, Rita Wahyuni Arifin, Ahmad Safei, Rayhan Wahyudin Ratu

Vol. 3 No 2, Agustus 2021

ISSN 2657-0203

e-ISSN 2686-0244

misi dari SMK Telekomunikasi Telesandi Bekasi maka perlu dilakukan pelatihan pengenalan android dan pembuatan video streaming

dengan android studio pada SMK Telekomunikasi Telesandi Bekasi.

\section{Permasalahan Mitra}

Adapun permasalahan yang terjadi pada saat ini di SMK Telekomunikasi Telesandi Bekasi adalah: 1) Kurangnya memahami dasar android, 2) Kurangnya memahami aplikasi yang dapat digunakan dalam merancang aplikasi mobile, 3) Kurangnya memahami mengenai penggunaan aplikasi Android Studio.

\section{METODE}

Kegiatan PkM Online "Pengenalan Android dan Pembuatan Video Streaming Dengan Android Studio Pada SMK Telekomunikasi Telesandi " dilakukan secara daring melalui aplikasi Zoom dengan fasilitas Universitas Bina Insani dengan jumlah trainer sebanyak 1 (satu) orang, 1 (satu) orang moderator dan 3 (tiga) orang supporting untuk kegiatan PkM tersebut. Penerapan Lockdown atau Pembatasan Sosial Berskala Besar (PSBB) diyakini merupakan cara paling ampuh untuk menekan laju penularan pandemi Corona Virus atau Covid 19 (Thorik, 2020). Sehingga pelatihan ini dilakukan secara daring dari rumah masing-masing. Kegiatan Pelatihan Pengenalan Android dan Pembuatan Video Streaming Dengan Android Studio” diinformasikan melalui

media-media yang dijelaskan sebagai

berikut: 1) Media Online Zoom Meeting, Untuk dapat mengikuti kegiatan pelatihan Pengenalan Android dan Pembuatan Video Streaming Dengan Android Studio.

Peserta pelatihan dapat

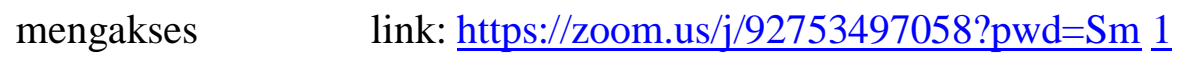

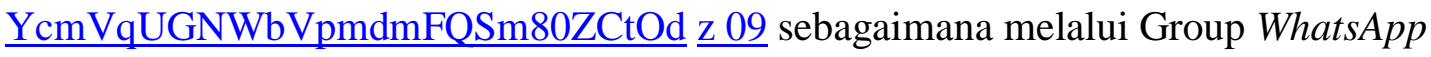
disampaikan oleh pihak Fakultas Informatika sebagai fasilitator kegiatan, 
Vol. 3 No 2, Agustus 2021

ISSN 2657-0203

e-ISSN 2686-0244

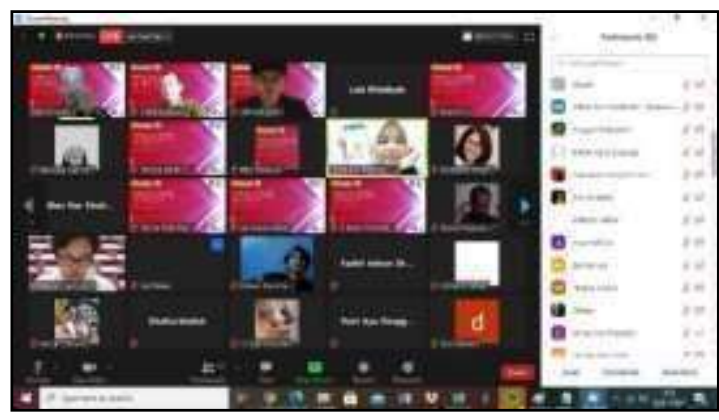

Gambar 2. Kegiatan PkM via Zoom Meeting

2) Media Online Youtube, Kegiatan PkM Pelatihan Online "Pengenalan Android dan Pembuatan Video Streaming Dengan Android Studio” juga disiarkan secara Live melalui saluran/chanel resmi youtube Bina Insani University via link: https://www.youtube.com/watch?v=quxH J wd5SIU.

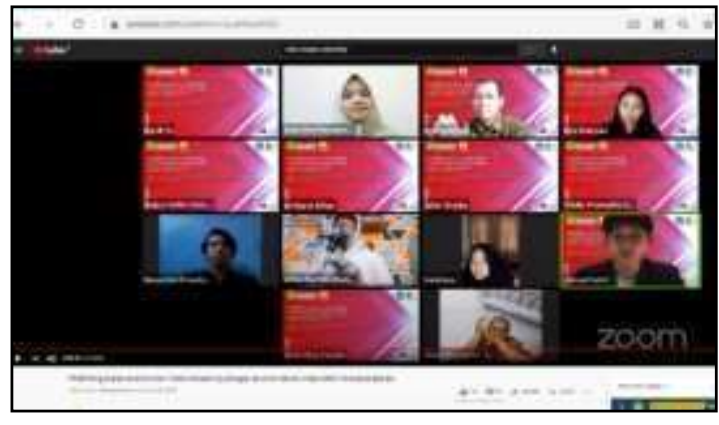

Gambar 3. Kegiatan PkM via Youtube

\section{HASIL DAN PEMBAHASAN}

Setelah selesai mengikuti pelatihan ini diharapkan seluruh peserta dapat memahami konsep Pengenalan Android dan Pembuatan Video Streaming Dengan Android Studio. Kegiatan ini juga sebagai target capaian dari implementasi kerjasama Universitas Bina Insani dengan SMK Telekomunikasi Telesandi dan untuk mendukung isian borang kriteria 9 Akreditasi Perguruan Tinggi dan Akreditasi Program Studi. Wujud dari target pencapaian kegiatan $\mathrm{PkM}$ dapat dilihat melalui jumlah peserta pendaftar dan 
respon feedback dari peserta setelah mengikuti kegiatan PkM yang diberikan melalui link google form http://bit.ly/angketpkmandroidstudio ada sebanyak 76 (tujuh puluh enam) responses. Adapun hasilnya adalah sebagai berikut: 1) Materi yang disampaikan oleh narasumber hasilnya terdapat $56,6 \%$ yang memberikan respon baik sekali dan $38,2 \%$ yang memberikan respon baik.

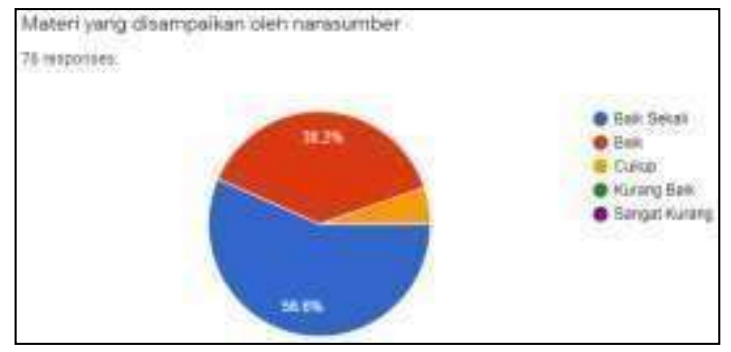

Gambar 4. Hasil Feedback terhadap materi yang disampaikan narasumber

, 2) Respon peserta pelatihan terhadap materi yang disampaikan, hasilnya terdapat $38,2 \%$ yang memberikan respon baik sekali, 59,6\% yang memberikan respon baik.

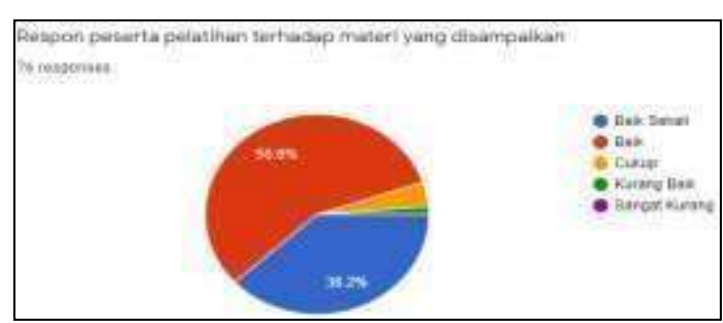

Gambar 5. Hasil Feedback terhadap respon peserta terhadap materi yang disampaikan

, 3) Hubungan materi yang disajikan dengan kebutuhan peserta pelatihan, hasilnya ada $43.4 \%$ yang memberikan respon baik sekali, dan ada $48.7 \%$ dari 76 
Intan Dwi Fatmaningtyas, Jafar Shadiq, Rita Wahyuni Arifin, Ahmad Safei, Rayhan Wahyudin Ratu

Vol. 3 No 2, Agustus 2021

ISSN 2657-0203

e-ISSN 2686-0244

responses yang memberikan respon baik dan $7,9 \%$ yang memberikan respon cukup.

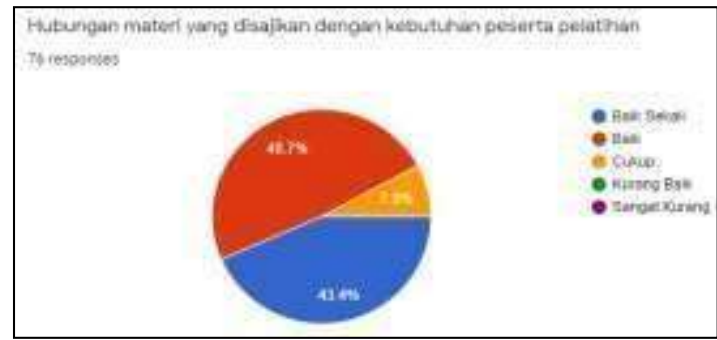

Gambar 6. Hasil Feedback terhadap

Hubungan materi yang disajikan dengan kebutuhan peserta

, 4) Keterkaitan antara materi dengan aplikasi yang dapat diserap peserta pelatihan, hasilnya ada $36,8 \%$ yang memberikan respon baik sekali, ada $51,3 \%$ yang memberikan respon baik dan $11,8 \%$ yang memberikan respon cukup.

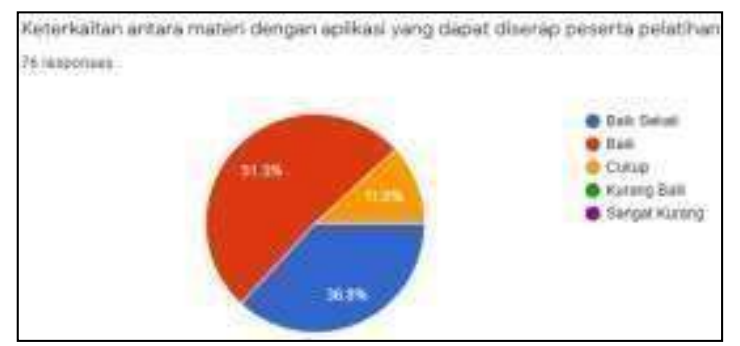

$50 \%$ yang memberikan respon baik dan $13,2 \%$ respon cukup baik.

Gambar 7. Hasil Feedback keterkaitan materi dengan an

,5) Keterkaitan materi dengan kebutuhan, hasilny

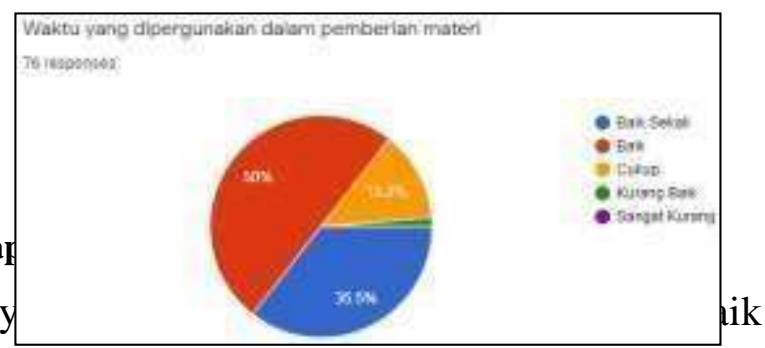
sekali, ada $47,4 \%$ yang memberikan respon baik dan $11.8 \%$ respon cukup.

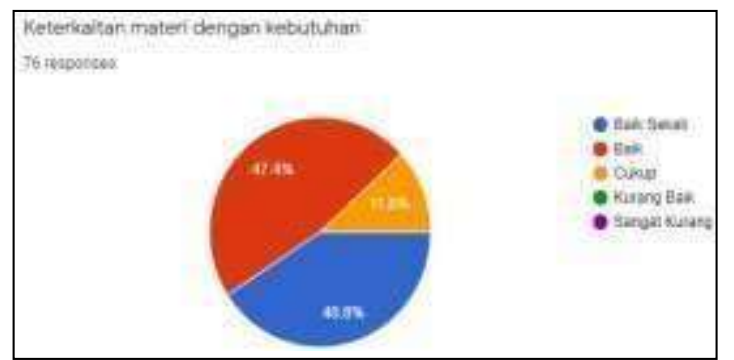

\section{Gambar 8. Hasil Feedback keterkaitan materi dengan kebutuhan}

, 6) Pemateri dan Teknik Penyajian, hasilnya ada 43,4\% yang memberikan respon baik sekali, ada $51,3 \%$ yang memberikan respon baik. 
Vol. 3 No 2, Agustus 2021

ISSN 2657-0203

e-ISSN 2686-0244

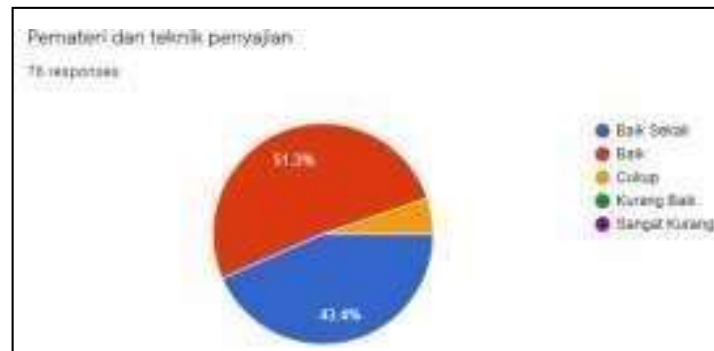

Gambar 9. Hasil Feedback pemateri dengan teknik penyajian

,7) Waktu yang dipergunakan dalam pemberian materi, hasilnya ada 35,54\% yang memberikan respon baik sekali, ada

\section{Gambar 10. Hasil Feedback waktu yang dipergunakan dalam pemberian materi}

, 8) Kejelasan materi, hasilnya ada 32,9\% yang memberikan respon sangat jelas, ada 52,6\% yang memberikan respon jelas dan $14,5 \%$ respon cukup jelas.

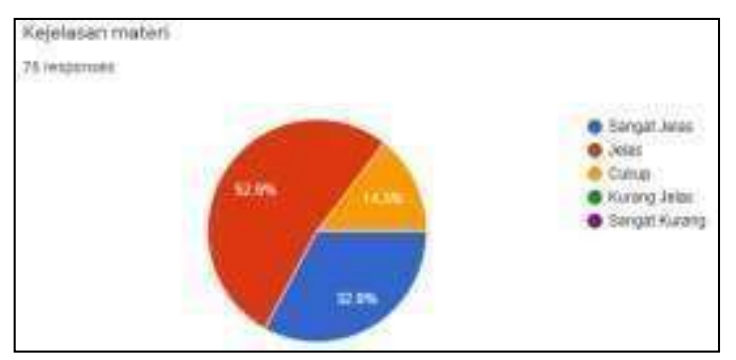

Gambar 11. Hasil Feedback kejelasan materi

, 9) Minat peserta pelatihan terhadap kegiatan, hasilnya ada 31,6\% yang memberikan respon baik sekali, ada $56,6 \%$ yang memberikan respon baik dan $11,8 \%$ respon cukup baik.

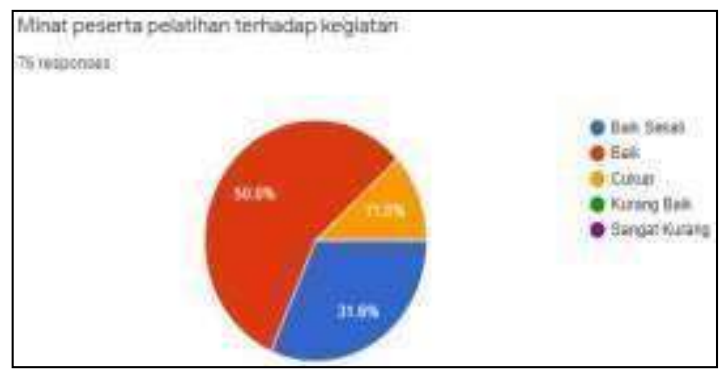

Gambar 12. Hasil Feedback minat peserta pelatihan terhadap kegiatan

, 10) Tingkat kepuasan terhadap kegiatan secara keseluruhan, hasilnya ada 31,6\% yang memberikan respon sangat puas, ada

$55,3 \%$ yang memberikan respon puas dan $13,2 \%$ respon cukup puas. 


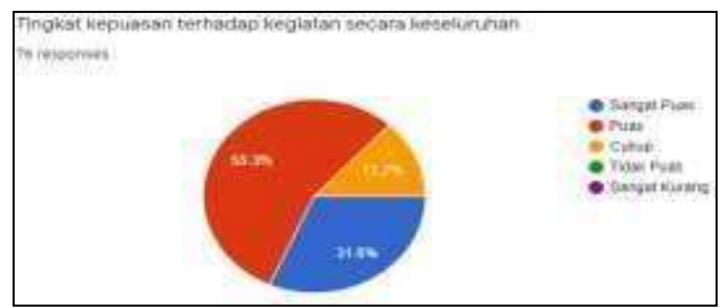

Gambar 13. Hasil Feedback tingkat kepuasan terhadap kegiatan secara keseluruhan

, 11) Saran untuk materi pelatihan yang akan datang adalah" Cukup baik dan sangat jelas", "Tidak ada, sudah bagus" serta "dibuatkan materi yang lebih memacu kreativitas lagi agar dapat memikat minat dan bakat siswa dalam dunia digital”.

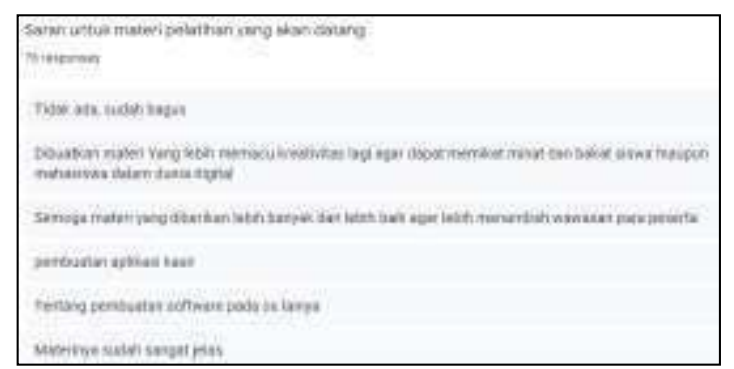

Gambar 14. Hasil Feedback saran untuk materi pelatihan yang akan datang

, 12) Saran untuk panitia kegiatan adalah "sudah cukup bagus" serta "agar lebih banyak dalam melakukan webinar",

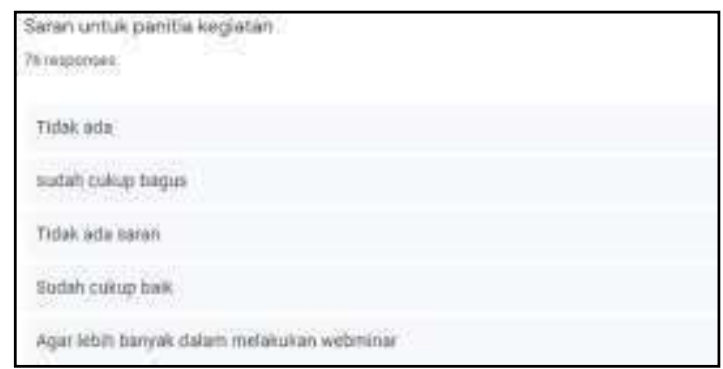

Gambar 15. Hasil Feedback saran untuk panitia kegiatan

\section{KESIMPULAN DAN SARAN}

Dengan adanya kegiatan Pengabdian kepada Masyarakat (PkM) ini sehingga dapat memberikan suatu pemahaman dalam pengenalan android dan pembuatan video streaming dengan android studio pada SMK Telekomunikasi Telesandi Bekasi. Berdasarkan hasil evaluasi umpan balik yang diperoleh dari hasil kuesioner umpan balik peserta secara keseluruhan kegiatan PkM ini dinilai 55.3\% memberikan respon puas terhadap kegiatan pelatihan. Semoga kegiatan PkM ini dapat bermanfaat bagi kita semua.

\section{DAFTAR PUSTAKA}

Al Fikri, I. (2016) ‘Aplikasi Navigasi Berbasis Perangkat Bergerak dengan Menggunakan Platform Wikitude untuk 
Studi Kasus Lingkungan ITS', Jurnal Teknik ITS, 5(1), pp. 48-51. doi: 10.12962/j23373539.v5i1.14511.

Pratama, Y. (2017) 'Pembuatan Aplikasi Streaming Audio Video Dan Informasi Kajian Studi Kasus Yayasan PemudaHijrah Indonesia',

p. 634. Available at: http://repository.unpas.ac.id/id/epri nt /31084\%0A.

Ramadhan, R. F. et al. (2020) 'Rancang Bangun Aplikasi Video Streaming Menggunakan Real Time Streaming Protocol ( RTSP )

Berbasis Android', Jurnal FTIK, 1, pp. 1133-1142.

Roihan, A. et al. (2019) 'Implementasi Metode Realtime, Live Data Dan Parsing JSON Berbasis Mobile Dengan Menggunakan Android Studio Dan PHP Native', 5(2).

Setiawan, A. R. and Mufassaroh, A. Z. (2020) 'Lembar Kegiatan Siswa untuk Pembelajaran Jarak Jauh Berdasarkan Literasi Saintifik pada Topik Penyakit Coronavirus 2019 (COVID-19)', Journal of Chemical Information and Modeling, 21(1), pp. $1-9$.

Thorik, S. H. (2020) 'Efektivitas Pembatasan Sosial Berskala Besar Di Indonesia Dalam Penanggulangan Pandemi Covid-19', Jurnal Adalah: Buletin Hukum dan Keadilan, 4 No. 1, pp. 115-120.

Wardani, A. and Ayriza, Y. (2020) 'Analisis Kendala Orang Tua dalam Mendampingi Anak Belajar di Rumah Pada Masa Pandemi Covid19', Jurnal Obsesi: Jurnal Pendidikan Anak Usia Dini, 5(1), p. 772. doi: 10.31004/obsesi.v5i1.705. 